\title{
PLANNING AND MANAGEMENT OF OPERATION THEATRE COMPLEX
}

\author{
Amit Goel1
}

${ }_{1}^{1}$ Senior Consultant, Department of Surgery, Jaipur Golden Hospital, Delhi.

\section{ABSTRACT}

\section{BACKGROUND}

Operation theatre are most important aspect of any hospital. Proper care should be given for planning and construction of operation theatre with strict International guidelines. The different aspects of planning, management and maintenance of operation theatre complex are enumerated.

\section{KEYWORDS}

Theatre, Operation, Planning, Management.

HOW TO CITE THIS ARTICLE: Goel A. Planning and management of operation theatre complex. J. Evolution Med. Dent. Sci. 2017;6(30):2471-2472, DOI: 10.14260/Jemds/2017/533

\section{BACKGROUND}

Operation theatres represent most critical and expensive hospital resources. Surgeons are getting conscious to standard of perioperative, operative and postoperative care provided to patients. Ensuring the safety profile for patient, it is required that proper techniques are followed. Operating room are high cost and revenue environments. It is essential to optimise the effectiveness of operating room. ${ }^{1}$ The components of operation complex should be known and guidelines present a pragmatic approach to judicious selection and proper use. The good design of operation theatre creates aesthetically pleasing configuration of operating rooms, space required for storage, administration, staff, provisions of sterile processing and systems to manage airborne contamination.

\section{Zones of Operation Theatre Complex}

The location and flow of patients, staff and materials form groups for design of operation theatre. The zones of operation complex are based on degrees of cleanliness, where bacterial count diminishes from outer to inner zones.

\section{Protective Zone}

It is change room for medical and paramedical staff, transfer bay for patients, material and equipment rooms for administrative staff. There is provision of storage and record rooms. There are pre- and post-operative rooms and intensive care unit.

\section{Clean Zone}

It connects protective zone to aseptic zone. It stores equipment, maintenance workshop, kitchenette, firefighting and emergency exits.

\section{Aseptic Zone}

It contains operating rooms and disposal zone.

Financial or Other, Competing Interest: None.

Submission 07-03-2017, Peer Review 30-03-2017,

Acceptance 06-04-2017, Published 13-04-2017.

Corresponding Author:

Dr. Amit Goel,

\#513/514, $1^{\text {st }}$ Floor Storey,

New Rajinder Nagar,

New Delhi.

E-mail: gamit11@rediffmail.com

DOI: $10.14260 /$ jemds $/ 2017 / 533$

\section{(c) (i) $\$$}

\section{DISCUSSION}

The oldest operation theatre of London is museum of surgical history built in 1822 before anaesthetics and antiseptic surgery.

Pennsylvania hospital, Philadelphia boasts of oldest surviving operation theatre built in 1804. The operation theatre was first of its kind and formalised surgery and turned it into a recognised medical discipline.

General surgeon, Gustav Neuber, implemented comprehensive set of restrictions to ensure septic conditions through use of gowns, caps, shoe covers which are cleaned by autoclave. $^{2}$

The ideal theatre should be low rise building, three-storey with advantage of ventilation. The OT room should have size of $6.5 \times 6.5 \times 3.5$. The size of doors should be $1.2 \times 1.5$ sliding. The windows should give visual appreciation. The surface and flooring should be with minimal joints, either mosaic or copper plates. The flooring, walls and ceiling should be nonporous, smooth, seamless without corners. The walls should be polyester and seamless. Electric points should be $1.5 \mathrm{~m}$ from floor. Corridors should have $2.85 \mathrm{~m}$ width. Oxygen, gas and suction pipe should be with central facility. There should be adequate elimination. The standard occupancy should be for $\mathrm{v}$ 5-7 persons and standard equipment load of 5-7 kw per OT. Temperature and humidity should be considered while designing the OT. The minimal air changes should be 30 based on International guidelines. The air flow should be unidirectional and downwards and air velocity of 90 - $120 \mathrm{fpm}$. The temperature should be maintained inside the operation complex with humidity of $55 \%$. There should be air purification and air filtration unit. The air conditioning requirement should be deliberated with manufacturers, engineers and technical committee members. Windows air conditioners are not used, because they are pockets of microbial growth. There should be one operation table per operation room, gas and suction for OT and preoperative and postoperative areas. There should be anaesthesia trolley, anaesthesia machine, central gas, suction pipes, imaging, $\mathrm{x}$-ray film illuminators, provision of continuous water supply, proper scavenging and drainage system. ${ }^{3}$

\section{Ophthalmic Operation Complex}

Ophthalmic OT should be enclosed, air conditioned with operating microscope, scrub area and tested water supply. Fumigations and negative culture are required to start an ophthalmic OT. 


\section{Design of Theatre Complex}

The outer zone consists of reception, clean zone is changing room and aseptic zone is gowning, gloving and operation room. There should be $6-9$ persons per OT. The flooring, walls and ceiling should be nonporous, seamless without corners. The number and size of operating rooms are variable, but recommended size is $6.5 \times 6.5 \times 3.5 \mathrm{~m}$. Glass windows should be planned on one side only. Electric points should be on the wall.

\section{Air Flow}

Air velocity should be able to carry bacteria and airflow should be unidirectional. Air is supplied through HEPA filters. Air quality should be class 1000 . Humidity should be $60 \%$. There should be air filtration and purification unit. There should be periodic temperature and humidity check, air velocity check and periodic maintenance should be carried. Air condition should be cleaned and serviced every month. Air conditioning should be recirculating and nonrecirculating. The non-circulating system conveys the air to operation room with 20 exchanges per operation theatre. The circulating system takes some of air, adjusts the temperature and circulates air back to room. ${ }^{4}$

\section{Cleaning of Theatre}

Fumigation should be carried with $30 \mathrm{~mL}$ of formalin for 1000 cubic feet by aerosol spray. ETO and autoclaving of instruments is mandatory. The bacterial count should be checked every fortnight. Sterrad is recommended if affordable to the Institution. There should be 6 sets of instruments autoclaved and kept available per OT. Surface of trolleys, operation table, microscope and furniture should be cleaned with antiseptic solution.

A well-designed system to provide automated records, material management, assessment and quality improvement should be there. Operation theatre cater to $50 \%$ of the needs to total health care seekers, $80 \%$ of which is surgeon controlled. ${ }^{5}$

Music in operation theatres does not disturb staff, but does not improve concentration. A study was conducted to investigate the effect of music in operation theatres on patient, surgeons and staff. Patients, surgeons and staff liked the music. Study concluded that music therapy during ophthalmic surgery is beneficial. 6

Honeywell gave building management system which recommends the use of magnetic gauges to monitor pressure, provide air risers to maintain flow, installation of HEPA filters with $99 \%$ efficiency. They postulated the maintenance of temperature, humidity and proper airflow pattern.

Operation theatre should have regulations according to municipal corporations, pollution control, firefighting department and water and sanitation departments. People for operation rooms should wear personal protective equipment to prevent infections which are caps, masks, glasses and gloves.

Operation room design should focus more on surgical environment than on process of care. Sandberg et al constructed three room suite including operation room, induction room and early recovery area. Deliberate operation room and perioperative redesign improved throughput performance. Performance improvement was derived from relocating and reorganising non-operative activity. ${ }^{7}$

\section{CONCLUSION}

It is important for proper planning of operation theatre complex in evidence-based medicine. Efforts should be made to conform to standards of local and International agencies. Improving perioperative systems could increase operation room efficiency.

\section{REFERENCES}

[1] Krupka DC, Sandberg WS. Operation room design and its impact on operation room economics Curr opin anaesthesiol 2006;19(2):185-91.

[2] Deysine M. Hernia infections, pathophysiology, diagnosis, treatment, prevention. Inferna health care 2003;13.

[3] Hasoor SS, Bhasker SB. Design of ideal operating room complex. Ind J Anaesth 2007;51(3):193-9.

[4] Gupta SK, Kant S, Chandrashekhar R. Operating room planning, essentials and design considerations. Journal of academy of hospital administration 2005;17:1-12.

[5] Barash PG, Cullen BF, Stoelting RK. Value based anaesthesia, practice, resourse, utilization and operating room management. Clinical anaesthesia. Lippincott Williams and Wilkins 2001:111-2.

[6] Sarmany J, Kalman R, Staud D, et al. Role of music in the operation theatre. Orv Hetil 2006;147(20):931-6.

[7] Sandberg WS, Daily B, Egan M, et al. Deliberate perioperative systems design improves operation room throughput. Anaesthesiology 2005;103(2):40618. 